\title{
Pengaruh Variasi Warna Ransum terhadap Konversi Ransum dan Pertambahan Bobot Badan Harian Broiler
}

\author{
Maria Fatima Kolo ${ }^{\mathrm{a}}$, Oktovianus Rafael Nahak ${ }^{\mathrm{b}}$, dan Gerson Frans Bira ${ }^{\mathrm{c}}$ \\ ${ }^{a}$ Fakultas Pertanian, Universitas Timor, Kefamenanu, TTU - NTT, Indonesia, email: mariafatimakolo80@ gmail.com \\ ${ }^{b}$ Fakultas Pertanian, Universitas Timor, Kefamenanu, TTU - NTT, Indonesia, email: oktovianusrafael@yahoo.co.id \\ ${ }^{c}$ Fakultas Pertanian, Universitas Timor, Kefamenanu, TTU - NTT, Indonesia, email: gersonbira@yahoo.co.id
}

\section{Article Info}

\section{Article history:}

Received 13 Maret 2018

Received in revised form 26 Agustus 2018

Accepted 15 September 2018

DOI:

https://doi.org/10.32938/ja.v3i4.423

Keywords:

Warna Ransum

Broiler

Konversi Ransum

\section{Abstrak}

Tujuan dari penelitian ini mengetahui pengaruh pemberian ransum dengan warna berbeda terhadap nilai konversi ransum dan perta mbahan bobot badan harian (PBBH) broiler. Penelitian dilaksanakan pada bulan Januari - Februari 2018. Metode yang digunakan dalam penelitian ini adalah metode percobaan (eksperimen) dengan Rancangan Acak Lengkap (RAL) sebagai rancangan lingkungannya. Dalam penelitian ini menggunakan 4 perlakuan, dimana setiap perlakuan terdiri dari 4 ulangan. Setiap ulangan berisi 5 ekor broiler, sehingga total broiler yang digunakan adalah sebanyak 80 ekor. Adapun perlakuan yang akan diuji terdiri dari : (1) $R_{0}$ : Ransum berwarna coklat (2) $R_{1}$ : Ransum berwarna hijau (3) $R_{2}$ : Ransum berwarna merah (4) $R_{3}$ : Ransum berwarna kuning. Variabel pengamatan yang diamati yaitu pertambahan bobot badan dan konversi ransum. Hasil penelitian menunjukkan bahwa pemberian ransum warna coklat dapat meningkatkan berat badan sebesar $(384,00)$ dan konversi pakan terbaik dengan nilai terendah $(0,17)$ dibandingkan dengan perlakuan ransum berwarna hijau, merah dan kuning. Adanya variasi warna ransum yang ditambahkan dalam pakan tidak untuk menambah nilai nutrisi namun diharapkan dapat memberikan efek baik secara langsung maupun tidak langsung terhadap sifat khas dari pakan yang diberikan. Pemberian variasi warna (coklat, hijau, merah dan kuning) tidak memberikan pengaruh nyata terhadap pertambahan bobot badan broiler dan nilai konversi ransum.

\section{Pendahuluan}

Di Indonesia khususnya Provinsi Nusa Tenggara Timor (NTT) perkembangan peternakan broiler di kalangan masyarakat mengalami kemajuan yang sangat pesat. Perkembangan tersebut dikarenakan semakin meningkatnya permintaan masyarakat terhadap daging dalam rangka memenuhi kebutuhan protein. Broiler (ayam pedaging) merupakan jenis ternak yang banyak dikembangkan sebagai sumber pemenuhan kebutuhan protein hewani, karena memiliki sifat cepat bertumbuh dan sangat efisien dalam mengonversi ransum.

Faktor utama dalam menentukan keberhasilan pemeliharaan broiler adalah pakan. Pakan menghabiskan kurang lebih 60-70\% dari biaya produksi. Tingginya biaya produksi dalam bentuk biaya pakan dapat ditekan dengan penggunaan bahan pakan lokal yang harganya masih relatif murah. Dalam menyediakan ransum untuk broiler maka ada beberapa hal yang perlu diperhatikan salah satunya adalah bentuk fisik ransum meliputi ukuran (pellet dan gritss) dan warna. Unggas lebih menyukai pakan dalam bentuk butiran seperti pellet terhadap ransum dengan warna yang mencolok. Amrullah (2004) menyatakan bahwa penggunaan zat warna nyata meningkatkan konsumsi ransum, energi dan ransum pada ayam yang diberi makan bebas pilih kendati hanya untuk kombinasi warna hijau dan kuning.

Warna ransum juga membantu ternak ayam dalam tingkat konsumsi dengan memilih warna yang lebih cerah. Indikasi pemanfaatan warna dalam ransum dapat terlihat dari tingkat konsumsi dan daya tarik ayam terhadap ransum yang diberikan serta dapat diukur dari pertumbuhan bobot badan ayam yang lebih cepat dengan jumlah pakan yang dikonsumsi sangat efisien.

Dalam penelitian ini penambahan warna pada ransum bukan untuk pertumbuhan ternak akan tetapi hanya untuk meningkatkan palatabilitas ternak. Penambahan warna pada ransum menggunakan kesumba yang dicampurkan ke dalam ransum yang dibuat untuk diberikan pada ternak melalui beberapa jenis warna dengan tujuan untuk mendapatkan warna yang lebih unik dan cerah dari aslinya, ransum tampak lebih menarik dan lebih segar, meningkatkan daya tarik ayam terhadap ransum, memperbaiki tingkat kesukaan ayam terhadap ransum yang diberikan, menutupi perubahan warna akibat paparan cahaya, udara atau temperatur yang ekstrem akibat proses pengolahan dan selama penyimpanan serta untuk menjaga rasa dan vitamin yang mungkin akan terpengaruh sinar matahari selama produk disimpan (Syah $d k k$., 2005).

Tujuan dari penelitian ini mengetahui pengaruh pemberian ransum dengan warna berbeda terhadap nilai konversi ransum dan pertambahan bobot badan harian $(\mathrm{PBBH})$ broiler.

\section{Metode}

Penelitian dilaksanakan di kandang unggas milik Program Studi Peternakan, Fakultas Pertanian Universitas Timor selama 1 periode produksi (45) hari pada bulan Januari - Februari 2018. Kandang tipe lantai dengan 4 petak kandang berukuran $1 \times 0,5 \mathrm{~m}$, tinggi dinding kandang $50 \mathrm{~cm}$ dan tinggi alas $20 \mathrm{~cm}$ digunakan untuk menempatkan ternak perlakuan setiap kandang dilengkapi dengan tempat makan dan minum, timbangan duduk kapasitas $2 \mathrm{~kg}$ dengan tingkat kepekaan 50 gram untuk menimbang ternak dan timbangan Ohause untuk menimbang pakan. Bahan penyusun ransum yang terdiri dari : Jagung kuning, bungkil kelapa, gaplek, tepung ikan, daun turi dan dedak sebagai bahan dasar, sekam sebagai liter. Bahan dasar ransum dibeli dari masyarakat. Selain itu bahan lain yang digunakan yaitu HB1 dan vaksin ND lasota yang diberikan dalam bentuk tetes pada mata. Ternak yang digunakan dalam penelitian ini adalah day old chick (DOC) broiler jenis 707 Berjumlah 80 ekor. Bibit broiler yang dipakai dibeli di toko Mikro pertanian yang ada di kota Kefamenanu.

Metode yang digunakan dalam penelitian ini adalah metode percobaan (exprimen) dengan Rancangan Acak Lengkap (RAL) dengan menggunakan 4 perlakuan dan tiap perlakuan diulang sebanyak 4 kali. Setiap ulangan berisi 5 ekor broiler, sehingga total broiler yang digunakan adalah sebanyak 80 ekor. Adapun perlakuan yang telah diuji terdiri dari:

$\mathrm{R}_{0} \quad$ : Ransum berwarna coklat

\section{$\mathrm{R}_{1} \quad$ : Ransum berwarna hijau \\ $\mathrm{R}_{2} \quad$ : Ransum berwarna merah \\ $\mathrm{R}_{3} \quad$ : Ransum berwarna kuning}

Semua bahan baku pakan diolah menjadi tepung, selanjutnya menimbang semua bahan pakan yang telah disiapkan sesuai komposisinya masing-masing (Tabel 1.), setelah itu dicampurkan sampai merata dengan cara mencampurkan bahan pakan yang komposisinya lebih sedikit sampai dengan bahan yang komposisinya lebih banyak. Setelah semua bahan tercampur merata maka ransum tersebut dibagi dalam 4 bagian untuk diberi warna sesuai warna yang telah ditentukan. Pewarnaan terhadap ransum menggunakan kesumba dengan 4 warna yaitu coklat, hijau, merah dan kuning. Selanjutnya ransum yang telah diberi pewarna siap untuk dicetak dalam dua bentuk yaitu gritss dan pellet Setelah semua bahan pakan dicetak maka di pisahkan untuk di jemur sesuai dengan perlakuan masing-masing. Pakan yang disusun memiliki kandungan protein $21 \%$ dan EM $3278 \mathrm{kkal} / \mathrm{kg}$ (Tabel 2.).

\begin{tabular}{clc} 
Tabel 1. Komposisi Bahan Pakan & \\
\hline No. & Bahan Pakan & Satuan (\%) \\
\hline 1. & Jagung lokal & 40,00 \\
2. & Bungkil kelapa & 18,00 \\
3. & Daun turi & 24,00 \\
4. & Tepung ikan & 9,00 \\
5. & Dedak & 7,00 \\
6. & Gaplek & 2,00 \\
\hline & Total & 100.00 \\
\hline
\end{tabular}

Tabel 2. Hasil Analisis Bahan

\begin{tabular}{|c|c|c|c|c|c|c|c|}
\hline \multirow[b]{2}{*}{ No. } & \multirow[b]{2}{*}{ Kode Sampel } & \multicolumn{6}{|c|}{ Komposisi (\%) } \\
\hline & & Air & $\begin{array}{c}\text { Protein } \\
\text { kasar }\end{array}$ & $\begin{array}{c}\text { Lemak } \\
\text { kasar }\end{array}$ & $\begin{array}{l}\text { Serat } \\
\text { kasar }\end{array}$ & BETN & Abu \\
\hline 1 & $\mathrm{R}_{0}$ & 12,11 & 21,71 & 9,22 & 6,64 & 50,97 & 9,46 \\
\hline 2 & $\mathrm{R}_{1}$ & 12,54 & 21,70 & 8,19 & 6,13 & 50,89 & 10,09 \\
\hline 3 & $\mathrm{R}_{2}$ & 12,33 & 21,75 & 7,06 & 6,40 & 56,06 & 8,72 \\
\hline 4 & $\mathrm{R}_{3}$ & 15,13 & 21,69 & 6,78 & 5,81 & 49,72 & 11,00 \\
\hline
\end{tabular}

Pemberian ransum pada ternak ayam dilakukan 1 kali dalam sehari. Proses pemberiannya terdiri dari dua bentuk yaitu gritss untuk ayam berumur 4 sampai 14 hari dan pellet ketika ayam berumur 15 sampai 45 hari, air minum diberikan secara ad libitum. Pemeliharaan dilakukan terhadap kandang, tempat makan dan tempat minum, cahaya lampu, selain itu ternak tersebut diberi vaksin ND- Lasota dan HB 1 Hitcher. Data Pertambahan Bobot Badan Harian (PBBH) di ambil pada tiap minggu dengan menghitung selisih antara bobot badan akhir dengan bobot badan minggu sebelumnya sedangkan data konversi ransum dihitung dengan menggunakan data konsumsi yang diukur pada tiap hari. Variabel yang dilihat adalah pertambahan bobot badan harian $(\mathrm{PBBH})$. Sedangkan konversi ransum (gr/ekor/petak) dihitung berdasarkan Anggorodi (2005). Data dianalisis menggunakan analisis sidik ragam (Anova) sesuai dengan Rancangan Acak Lengkap (RAL), dilanjutkan dengan uji jarak berganda Duncan untuk melihat perbedaan antara perlakuan (Stell \& Torrie, 1989). Analisis data menggunakan Sofware SAS versi 9.1.

\section{Hasil dan Pembahasan}

\subsection{Pertambahan Bobot Badan Harian}

Ransum adalah bahan pakan ternak yang telah diramu dan biasanya terdiri dari berbagai jenis bahan pakan dengan komposisi tertentu. Pemberian ransum bertujuan untuk menjamin pertumbuhan berat badan dan menjamin produksi daging agar menguntungkan (Sudaro \& Siriwa, 2007). 
Pertambahan bobot badan adalah selisih antara berat badan akhir dengan berat badan awal dibagi total hari penelitian (gram/ekor/hari). Pengaruh perlakuan dengan jenis warna pakan yang berbeda yaitu ransum buatan dengan beberapa jenis warna terhadap rata-rata pertambahan berat badan ayam broiler terlihat pada Gambar 1.

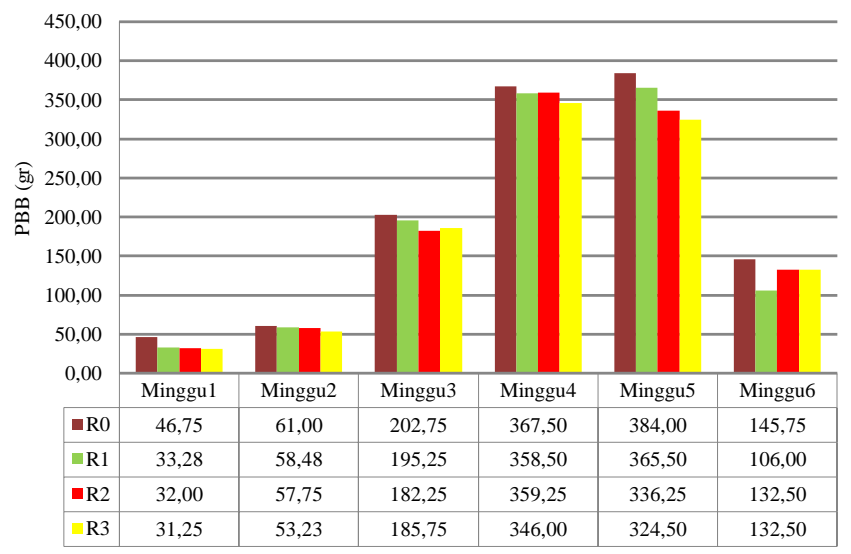

Gambar 1. Rataan Pertambahan Bobot Badan Broiler (gram/ekor/minggu)

Pada Gambar 1. terlihat bahwa rata-rata pertambahan berat badan ternak ayam broiler yang mengonsumsi ransum buatan yang berwarna cokelat pada minggu 1, minggu 2, minggu 3, minggu 4 dan minggu 5 menunjukkan laju pertambahan berat badan lebih tinggi di bandingkan warna ransum lainnya. Laju pertambahan berat badan mencapai puncaknya pada minggu ke 5 yaitu menghasilkan pertambahan berat badan sebesar 384,00 gr/ekor/minggu. Secara umum laju pertambahan berat badan pada semua jenis ransum membentuk kurva sikmodial dimana pertambahan berat badan tertinggi terjadi pada minggu ke 4 dan 5 .

Hasil analisis sidik ragam (Anova) menunjukkan bahwa pemberian perlakuan warna ransum baik R0, R1, R2 dan R3 dari minggu 1 sampai minggu ke 6 menunjukkan tidak berbeda nyata $(\mathrm{P}>0,01)$ sehingga dapat dikatakan bahwa antara pemberian ransum baik yang berwarna coklat, hijau, merah dan kuning secara statistik tidak memberikan pengaruh terhadap pertambahan bobot badan dan memiliki pengaruh yang sama terhadap pertambahan berat badan pada tiap minggu selama waktu pengamatan. Namun secara angka menunjukkan bahwa warna coklat sedikit lebih tinggi dari warna pakan yang lain. Hasil dari penelitian ini sedikit lebih rendah jika dibandingkan dengan Idayat $d k k$. (2012) yang memberikan pertambahan bobot badan ayam broiler sebesar 347, 99-360,13 g/ekor/hari. Hal ini disebabkan karena kandungan protein dan energi $(22,69 \%$ dan $2.935 \mathrm{Kkal} / \mathrm{kg}$ ) yang berbeda pula.

Menurut Tillman $d k k$. (1991) Pertumbuhan dapat dilihat pada kenaikan bobot badan yang diperoleh dengan cara menimbang ayam broiler secara harian, mingguan ataupun menurut periode waktu tertentu. Menurut Scott $d k k$. (1982) ayam broiler tumbuh relatif cepat pada hari pertama sampai 6 minggu. Pola pertumbuhan unggas dimulai secara perlahan lalu berlangsung lebih cepat dan akhirnya menurun kecepatannya atau berhenti sama sekali (Anggorodi, 1994). Demikian juga menurut Rasyaf (1994) bahwa pertumbuhan ayam pedaging sangat cepat dan pertumbuhan dimulai sejak menetas sampai umur 8 minggu, setelah itu kecepatan pertumbuhan akan menurun. Hal demikianlah yang digambarkan pada Gambar 1. Pada penelitian ini warna-warna ransum yang ditambahkan dalam pakan tidak untuk menambah nutrisi namun diharapkan untuk menghasilkan (langsung dan tidak langsung) suatu komponen yang mempengaruhi sifat khas makanan. Pernyataan-pernyataan ini juga mendukung tentang tidak ada pengaruh yang nyata dari warna pakan terhadap pertumbuhan bobot badan. Ayam broiler akan memperlihatkan pertambahan bobot badan yang sama apabila kandungan protein dan energi metabolisnya baik dan sama pula.

\subsection{Konversi Ransum}

Konversi pakan atau Feed Conversion Ratio adalah perbandingan antara konsumsi pakan dan pertambahan berat badan atau dapat dinyatakan sebagai efisiensi pakan, yaitu perbandingan berat badan per unit konsumsi pakan. Djulardi (2006) menambahkan konversi pakan adalah perbandingan konsumsi pakan dengan pertambahan bobot badan atau produksi telur. Dengan demikian konversi pakan terbaik adalah jika nilai terendah. Nilai konversi ransum ternak ayam broiler dalam penelitian ini dapat dilihat di Gambar 2.

Hasil analisis terhadap ransum yang diberi tambahan zat pewarna tidak berpengaruh nyata terhadap konversi ransum. Hal ini berhubungan dengan pertambahan bobot badan yang dihasilkan tidak nyata. Retnani $d k k$. (2009) menyatakan bahwa konversi ransum yang baik adalah kurang dari dua, nilai konversi berbanding terbalik dengan nilai efisiensi ransum, bila konversi ransum semakin rendah maka efisiensi ransum semakin tinggi dan sebaliknya bila konversi ransum tinggi maka efisiensi ransum semakin rendah. Pada penelitian ini konversi ransum yang dihasilkan cukup baik yang ditunjukkan pada Gambar 2. seiring dengan pertambahan bobot badan (Gambar 1).

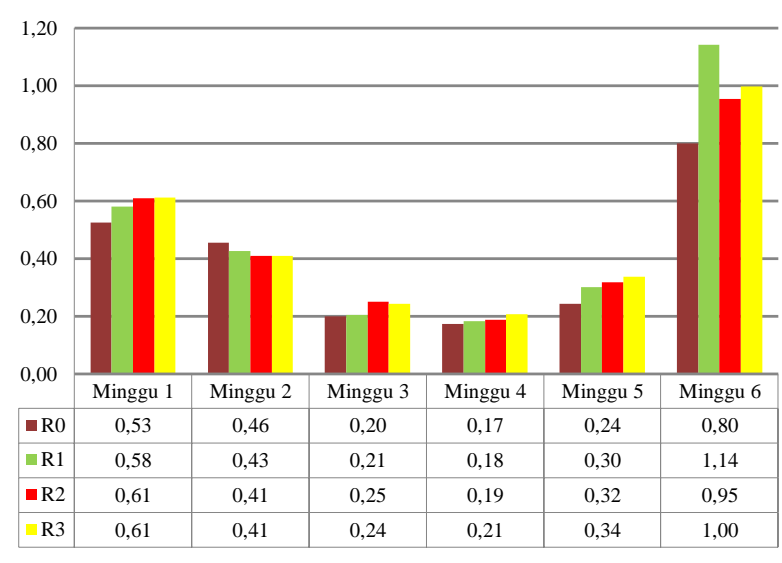

Gambar 2. Nilai Konversi Ransum

Namun, nilai konversi dari penelitian ini belum mencapai standar nilai konversi broiler yang distandarkan oleh Murtidjo (1987) yakni 1,535-1,885. Hal ini kemungkinan besar diakibatkan oleh suhu lingkungan $\left(30^{\circ}-31^{\circ} \mathrm{c}\right)$ yang sangat tinggi dan kelembaban $(64 \%)$ pada daerah penelitian sehingga nutrisi yang berasal dari pakan sepenuhnya dipakai untuk mempertahankan hidup dari cekaman stres lingkungan yang didapat broiler. Hal senada diungkapkan oleh Idayat $d k k$. (2012) bahwa nilai konversi ransum yang tidak sesuai dengan standar nilainya kemungkinan disebabkan karena jumlah ransum yang dikonsumsi tidak sepenuhnya untuk produksi melainkan lebih banyak digunakan menyesuaikan suhu tubuh dengan suhu lingkungan.

\section{Simpulan}

Pemberian variasi warna (coklat, hijau, merah dan kuning) tidak memberikan pengaruh yang nyata terhadap pertambahan bobot badan harian dan nilai konversi ransum broiler. Adanya variasi warna ransum yang ditambahkan dalam pakan tidak untuk menambah nilai nutrisi namun diharapkan dapat memberikan efek baik secara langsung maupun tidak langsung terhadap sifat khas dari pakan yang diberikan.

\section{Pustaka}

Amrullah I. K. 2004. Manajemen Ternak Ayam Broiler. Bogor: IPB Press. Anggorodi. 2005. Ilmu Makanan Ternak Umum. Jakarta: PT. Gramedia. Anggorodi. 1994. Ilmu Makanan Ternak Umum. Jakarta: PT. Gramedia. Djulardi, A., H. Muis \& S. A. Latif. 2006. Nutrisi Aneka Ternak dan Satwa Harapan. Padang: Andalas University Press.

Idayat A. U. Atmomarsono, W. Sarengat. 2012. Pengaruh Berbagai Frekuensi Pemberian Pakan Pada Pembatasan Pakan Terhadap Performans Ayam Broiler. Animal Agriculture Journal. 1(1): 379-388.

Murtidjo B. A. 1987. Pedoman Meramu Pakan Unggas. Cetakan 1. Yogyakarta: Kanisius.

Rasyaf M 1994. Makanan Ayam Broiler. Yogyakarta: Yayasan Kanisius.

Retnani Y. E. Suprapti. I, Firmansyah, L. Herawati da R. Mutia. 2009. Pengaruh Penambahan Zat Pewarna Dalam Ransum Ayam Broiler Terhadap Penampilan, Persentase Berat Bursa Fabrisius, Karkas dan Organ Dalam. J. Indon. Trop. Anim. Agric. 34(2).

Scott M. L. M. C. Nesheim \& R. J. Young, 1982. Nutrition of The Chicken. 3rd Ed. M. L. Scott \& Association, NewYork: Ithaca.

Stell and Torrie 1989. Prinsip dan Prosedur Statistika: Suatu Pendekatan Biometrik. Jakarta: P. T. Gramedia.

Sudaro, Y \& A. Siriwa. 2007. Ransum Ayam dan Itik. Cetakan IX. Jakarta: Penebar Swadaya.

Syah 2005. Manfaat dan bahaya bahan tambahan pagan. Himpunan Alumni Fakultas Teknologi Pertanian : IPB.

Tillman A. D. S. Reksohadiprojo, S. Prawirokusumo, dan S. Lebdosekejo. 1991. Ilmu Makanan Ternak Dasar. Yogyakarta: Gadjah Mada University Press. 